\title{
SOSIALISASI MENINGKATKAN JIWA BERWIRAUSAHA PADA MASYARAKAT DESA MULYASEJATI
}

\author{
${ }^{1}$ Asep Jamaludin, ${ }^{2}$ Wanta, ${ }^{3}$ Yudi Firmansyah \\ asepjamaludin@ubpkarawang.ac.id \\ wanta@ubpkarawang.ac.id \\ yudifirmansyah@ubpkarawang.ac.id
}

\begin{abstract}
Abstrak : Pengabdian Pada Masyarakat ini bertujuan mengacu pada tema yang telah ditentukan yaitu Peningkatan jiwa berwirausaha pada masyarakat mulyasejati. Subjek yang menjadi sasaran dalam Pengabdian Pad Masyarakat ini adalah masyarakat desa mulyasejati. Kegiatan yang dilaukukan yaitu memberikan sosialisasi untuk meningkatkan jiwa berwirausaha kepada masyarakat dalam rangka meningkatkan kesejahteraan masyarakat di Desa Mulyasejati, juga memberikan informasi mengenai inovasi terhadap produk itu sangat penting guna melancarkan dan mempertahankan market, dan meningkatkan kesadaran bahwa kemasan, label, setfikat, dan lain-lain itu perlu. Adapun manfaat yang di dapatkan yaitu Masyarakat dapat memiliki pengetahuan dan keterampilan untuk berwirausaha dalam meningkatkan ekonomi keluarga, juga bertujuan untuk meningkatkan kesaradaran akan pentingnya inovasi dalam suatu produk dan membantu sebuah usaha yang di olah untuk mengembangkan produk dalam segi pemasarannya, juga membantu mengembangkan pemasaran usaha UMKM agar usaha tersebut dapat berkembang dengan baik dan memberikan sedikit inovasi dari produk juga dapat membuka peluang untuk memperluas pasar, pengembangan produk, yaitu dengan memperkenalkan produk baru yang orisinil. Metode yang digunakan dalam Pengabdian Pad Masyarakat ini adalah sosialisasi tentang berwirausaha dengan menggunakan ceramah dengan teknik presentasi dan Tanya jawab. Hasil Pengabidan Pada Masyarakat ini sangat baik hal ini dapat dilihat dari antusiasnya para peserta dalam megikuti kegiatan ini ditandai dengan banyaknya peserta sosialisasi berwirausaha ini dalm bertanya kitaka dilakukan diskusi dan Tanya jawab.
\end{abstract}

Kata Kunci : Meningkatkan, Berwirausaha 


\section{PENDAHULUAN}

Indonesia merupakan salah satu negara yang memiliki jumlah penduduk terbanyak di dunia. Indonesia juga memiliki sumber daya alam yang sangat melimpah, dan salah satu negara dengan penyumbang sumber daya manusia paling banyak di dunia. Terbukti bahwa tiap tahun Indonesia selalu mengirimkan tenaga kerja ke berbagai negara di Asia maupun dunia.

Pertumbuhan penduduk di Indonesia dari tahun ke tahun semakin meningkat. Menurut Ir. Joko Widodo dalam Hidayat (2016) saat ini jumlah penduduk Indonesia mencapai 252 juta orang per Januari 2016. Setiap tahun pertumbuhan penduduk di Indonesia naik sebesar 1,3 persen, itu artinya setiap tahun ada tambahan 3 juta orang. Jika dirata-rata, di Indonesia 1 wanita dapat melahirkan 2-3 anak. Ir. Joko Widodo memprediksi 15 tahun yang akan datang, Indonesia mempunyai penduduk dengan umur produktif yang sangat besar. Besarnya jumlah penduduk ini mempunyai arti bahwa pemerintah harus menyiapkan lapangan kerja. Seiring dengan pertambahan jumlah penduduk dan perubahan era pada industrialisasi menimbulkan masalah baru juga di dalamnya. Masalah tersebut antara lain menipisnya lapangan pekerjaan, jumlah pencari kerja yang mayoritas 2 merupakan lulusan sarjana meningkat sedangkan lapangan pekerjaan yang ada semakin menipis yang berakibat pada pengangguran. Pengangguran merupakan masalah utama yang sedang dihadapi oleh masyarakat Indonesia saat ini. Terlebih dengan adanya era Masyarakat Ekonomi Asean (MEA) semakin menambah terdesaknya masyarakat Indonesia yang tergeser oleh tenaga asing yang bekerja di Indonesia.

Pengangguran terjadi karena perbandingan pencari pekerjaan yang terlalu banyak di segala level pendidikan mulai dari tingkat SMP sampai dengan perguruan tinggi tidak sebanding dengan pekerjaan yang tersedia, itu terjadi tidak hanya di Indonesia saja, melainkan juga di seluruh dunia dan pada berbagai sektor antara lain industri, pertambangan, transportasi dan lain-lain (Saiman, 2009: 22). Data statistik menunjukkan bahwa tingkat pengangguran di Indonesia masih cukup tinggi, hal tersebut dapat dibuktikan dengan survey yang telah diadakan oleh Badan Pusat Statistik pada Agustus 2015 yaitu jumlah tingkat pengangguran terbuka sebesar 7,56 juta jiwa yang meningkat dari tahun sebelumnya sebesar 320 ribu jiwa dari 7,24 juta jiwa, Suhariyanto (dalam Ali, 2015) atau meningkat dari bulan Agustus 2015 sebesar 6,18 persen dibanding TPT Februari 2015 (5,81 persen) dan TPT Agustus 2014 (5,94 persen). 
Sedangkan untuk data terakhir yang diperoleh dari BPS, bulan Februari 2016 menunjukkan pengangguran lulusan perguruan tinggi meningkat persentasenya dari 5,34 persen menjadi 6,22 persen. Hal tersebut masih menunjukkan bahwa tingkat pengangguran di Indonesia masih cukup tinggi. Menurut para ahli, suatu negara dapat dinyatakan sebagai negara maju salah satu 3 indikatornya adalah minimal 2 persen dari jumlah penduduknya melakukan wirausaha. Salah satu cara yang dapat mengurangi pengangguran adalah dengan kewirausahaan. Menurut Hendro (2011: 29) kewirausahaan merupakan suatu kemampuan untuk mengelola sesuatu yang ada dalam diri untuk ditingkatkan agar lebih optimal sehingga bisa meningkatkan taraf hidup di masa mendatang. Menurut Saiman (2009: 43) kewirausahaan adalah suatu upaya dalam penciptaan kegiatan bisnis atas dasar kemauan dan keinginan dari diri sendiri. Dengan kewirausahaan, maka dapat menciptakan lapangan pekerjaan yang luas, tidak bergantung kepada orang lain dalam mendapatkan pekerjaan dan dapat membantu pemerintah dalam mengurangi pengangguran dengan cara membuka lapangan pekerjaan. Saiman (2009: 43) juga menambahkan bahwa wirausaha merupakan orangorang yang memiliki sifat-sifat kewirausahaan seperti berani mengambil risiko, pantang menyerah dan memiliki kemauan keras untuk sukses dalam mengelola bisnisnya berdasarkan kemampuan dan kemauan sendiri. Selain itu, seorang wirausaha juga memiliki penghasilan yang lebih besar dibandingkan dengan menjadi karyawan. Kewirausahaan juga dapat membantu meningkatkan pendapatan dalam negeri melalui sektor pajak. Sebelum meningkatkan jumlah wirausaha dan menekan angka pengangguran di Indonesia, masyarakat harus disadarkan dengan pentingnya meningkatkan minat berwirausaha. Minat dapat diartikan sebagai rasa senang atau ketertarikan terhadap sesuatu.

Kemudian, menurut Fuadi \& Fadli (2009: 93) minat berwirausaha merupakan suatu ketertarikan, keinginan dan ketersediaan seseorang melalui ide 4 dan inovasi yang dimiliki untuk bekerja keras untuk memenuhi kebutuhan hidupnya tanpa rasa takut dengan risiko yang akan terjadi, dapat menerima tantangan, percaya diri, kreatif dan inovatif, serta memiliki kemampuan dalam memenuhi kebutuhannya. Minat menjadi wirausaha didefinisikan sebagai keinginan seseorang untuk bekerja mandiri atau menjalankan usahanya sendiri. Minat untuk mulai berwirausaha pada mahasiswa sebenarnya sudah cukup tinggi, namun bayangan kegagalan, tidak memiliki modal yang cukup dan tidak memiliki waktu untuk fokus dalam mengembangkan usahanya menjadi risiko yang menghambat mahasiswa untuk memulai usahanya sendiri. Budiati, Yani \& Universari (2012) menyatakan bahwa minat mahasiswa menjadi wirausaha dibagi dalam empat kelompok yaitu: 1) Minat untuk memulai wirausaha dalam jangka waktu dekat, 2) Minat untuk memulai wirausaha dua tahun mendatang, 3) Minat untuk 
memulai wirausaha untuk jangka panjang, dan 4) Tidak memiliki minat berwirausaha. Minat pada dasarnya tidak dapat dipaksakan pada diri seseorang, karena minat merupakan hak bagi setiap manusia. Faktor yang mempengaruhi minat berwirausaha menurut Bygrave dalam (Buchori, 2011: 11) antara lain personal, environment dan sosiological.

Permasalahan ini juga terdapat di desa Mulyasejati yang terletak di Kec. Pangkalan, masyarakatnya masih banyak yang tidak mempunyaipekerjaan, juga kurang dalam berwirausaha untuk menciptakan lapangan kerja sendiri, dikarenakan beberapa factor, diantaranya : tidak ada modal, tidak mempunyai pengetahuan usaha apa yang harus dibuat, sudah mencoba untuk membuat usaha akan tetapi mengalami kegagalan sehingga tidak mau lagi meneruskan usahanya, dll.

Mengacu pada permasalahan yang telah dijelaskan, maka penulis berinisiatip untuk mengadakan Pengabdian Pada Masyarakat ini dengan mengangkat tema Sosialisasi Meningkatkan Jiwa Berwirausaha Pada Masyarakat Mulyasejati, kegiatan ini bertujuan : 1. Meningkatkan kemauan masyarakat desa mulyasejati untuk berwirausaha. 2. Meningkatkan pemahaman masyarakat desa mulyasejatii tentang berwirausaha.

\section{METODE}

Beberapa permasalahan yang terdapat di desa mulyasejati adalah terdapat beberapa masyarakat yang tidak punya pekerjaan dan kurangnya keinginan masyarakat untuk berwirausaha dikarenakan beberapa faktor diantaranya yaitu : bayangan kegagalan, tidak memiliki modal yang cukup dan tidak memiliki waktu untuk fokus dalam mengembangkan usahanya menjadi risiko yang menghambat mereka untuk berwirausaha sendiri, ada juga mereka sudah memeiliki usaha tapi tidak tau bagaimana cara memasarkan produknya tersebut, sehingga inilah yang menyebabkan kami mengadakan Pengabdian Pada Masyarakat di desa mulyasejati. Kegiatan ini dikemas dalam bentuk sosialisasi yang berupa pemahaman bagaimana cara memulai berwira usaha juga memberikan kepada masyarakat bagaimana cara mengembangkan usahanya.

Langkah-langkah kegiatan

Berikut ini adalah langkah-langkah sosialisasi yang dilakukan :

1. Tahap Persiapan Tahap persiapan yang dilakukan meliputi :

a. Survey

b. Pemantapan dan penentuan lokasi dan sasaran Penyusunan bahan/materi sosialisasi, yang meliputi : makalah dan modul untuk kegiatan Pengabdian Pada 
Masyarakat dengan tema "Sosialisasi Meningkatkan Jiwa Berwirausaha Pada Masyarakat Mulyasejati”

2. Tahap Pelaksanaan

Pada pelaksanaan kegiatan sosialisasi ini dilakukan persiapan, dalam kegiatan ini dilakukan beberapa tahapan: (1) penjelasan tentang alasan kenapa harus berwirausaha?, pada tahap ini menitikberatkan pada pemberian penjelasan mengenai pengetahuan untuk memotivasi dan meningkatkan masyarakat desa mulyasejati agar berkeinginan wirausaha. (2) penjelasan tentang usaha apa yang sebaiknya harus pertama kali dibuka, Pada tahap ini menitikberatkan pada memberikan pemahaman pengetahuan kepada masyarakat desa mulya sejati sebaiknya usha apa yang harus dibuka. (3) Cara mendapatkan modal untuk berwirausaha, pada tahap ini menitikberatkan bagaimana caranya agar kita mendaptkan modal usaha. (4) berinovasi dan memanfaatkan teknologi dalam memasarkan usahanya, pada tahapini masyarakat diberikan pemahaman bagaimana cara berinovasi dalam berwirausaha dan cara memasarkan usahanya agar berkembang dengan memanfaatkan teknologi.

3. Metode Pelatihan Untuk melaksanakan kegiatan tersebut digunakan beberapa metode pelatihan, yaitu :

a. Metode Ceramah Metode ceramah dipilih untuk memberikan penjelasan tentang Sosialisasi agar dapat meningkatkan jiwa berwirausaha pada masyarakat mulyasejati.

b. Metode Tanya Jawab Metode tanya jawab sangat penting bagi para peserta pelatihan, baik di saat menerima penjelasan tentang berwirausaha serta saat mempraktekkannya, Metode ini memungkinkan masyarakat mdesa mulyasejati menggali pengetahuan sebanyak-banyaknya berwirausaha dan memasarkan usahanya.

c. Metode Simulasi Metode simulasi ini sangat penting diberikan kepada para peserta pelatihan untuk memberikan kesempatan mempraktekan materi sosialisasi yang diperoleh. Harapannya, peserta sosialisasi akan benar-benar menguasai materi sosialisasi yang diterima, mengetahui tingkat kemampuannya menerapkan kegiatan berwirausaha secara teknis dan kemudian mengidentifikasi kesulitan kesulitan (jika masih ada) untuk kemudian dipecahkan.

\section{HASIL DAN PEMBAHASAN}

Kegiatan Pengabidan Pada Masyarakat dengan tema Sosialisasi Meningkatkan Jiwa Berwirausaha pada masyarakat Desa Mulyasejati ini dilaksankan pada tanggal 27 Agustus 2018. Kegiatan sosialisasi ini berjalan dengan lancar dihadiri oleh 40 peserta 
undangan. Peserta sosialisasi terlihat antusias dengan materi yang diberikan. Hal ini terlihat dari awal hingga akhir acara, semua peserta mengikuti dengan baik.

Berdasarkan hasil kegiatan dapat diidentifikasi mengenai tingkat pemahaman peserta pengabdian adalah bahwa $70 \%$ peserta pengabdian memahami sosialisasi untuk meningkatkan jiwa berwirausaha ini untuk meningkatkan kesejahteraan hidup masyarakat desa mulyasejati. Hasil pelaksanaan Pengabdian Pada Masyarakat menunjukkan masih terdapat banyak kekurangnya karena peserta yang hadir hanya sebanyak 40 orang, pada kegiatan Pengabdian Pada Masyarakat yang tujuan utamanya adalah sosialisasi memberikan pemahaman berwirausaha ini para peserta sangat antusias dalam mengikuti seluruh kegiatan sosialisasi, baik dalam pemberian materi. Para peserta juga memperlihatkan antusiasnya ketika melakukan diskusi.

\section{SIMPULAN}

Berdasarkan hasil pelaksanaan kegiatan Pengabdian Pada Masyarakat dengan tema "Sosilisasi Meningkatkan Jiwa Berwirausaha Pada Masyarakat Desa Mulyasejati", maka dapat disimpulkan bahwa kegiatan Pengabdian Pada Masyarakat ini berupa sosialisasi dan pendampingan dapat dilaksanakan dengan baik. Sosialisasi ini dilakukan selama 1 hari. Peserta yang hadir sebanyak 40 peserta yang hadir. Tim Pengabdian Pada Masyarakat dapat bekerjasama dengan kepala desa dan aparat desa dengan baik sehingga kegiatan ini dapat berjalan tertib dan lancar.

\section{DAFTAR PUSTAKA}

Hidayat, A. (2016). "Tiap Tahun Penduduk Indonesia Bertambah 3 Juta Orang". http://tempo.co pada 18 September 2018.

Saiman, L. (2009). Kewirausahaan, Teori, Praktik, dan Kasus-kasus. Jakarta: Salemba Empat.

Ali, F. (2015). "BPS: Tingkat Pengangguran Terbuka Meningkat dari Tahun Sebelumnya". http://Bisniskeuangan.kompas.com pada tanggal 18 September 2018.

Hendro. (2011). Dasar-dasar Kewirausahaan. Jakarta: Penerbit Erlangga.

Budiati, Y., Yani, T. E., \& Universari, N. (2012). Minat mahasiswa menjadi wirausaha (studi mahasiswa fakultas ekonomi universitas Semarang. Jurnal DINAMIKA SOSBUD, 14(1), 89-101. 
Jurna Buana Pengabdian

Vol. 1 No 1, Februari 2019

ISSN 2657-0203

79 Jurnal Buana Pengabdian 